\title{
Identifikasi Pengangguran Sukarela (Voluntary Unemployment) Perempuan di Kabupaten Kepahiang Tahun 2015
}

\author{
YOSEP OKTAVIANUS SITOHANG \\ Magister Statistika Terapan, FMIPA Universitas Padjadjaran \\ Email : yosep1707@gmail.com
}

\begin{abstract}
ABSTRAK
Penurunan angka pengangguran merupakan salah satu target pembangunan. Untuk merealisasikannya Pemerintah Daerah Kabupaten Kepahiang berusaha untuk menambahkan lapangan pekerjaan yang dapat menyerap tenaga kerja lokal yang ada. Namun pengangguran dapat dibagi kedalam dua kelompok, yaitu pengangguran terpaksa (involuntary unnemployment) dan pengangguran sukarela (voluntary unemployment). Kebijakan untuk menyamaratakan fenomena tersebut dirasa kurang tepat. Oleh karenanya perlu dilakukan pembuktian untuk membuktikan indikasi bahwa pengangguran perempuan di Kabupaten Kepahiang merupakan pengangguran sukarela. Dari hasil pengujian menggunakan Analisis tabel kontingensi 3 arah, Metode CochranMantel-Haenzel dan pengujian kehomogenan Odds Ratio didapat bahwa benar pengangguran perempuan di Kabupaten Kepahiang merupakan pengangguran sukarela (voluntary unemployment).

Kata Kunci: Pengangguran Sukarela, Tingkat Pendidikan, Status Kegiatan, Status Perkawinan, Analisis Tabel Kontingensi 3 arah, Metode Cochran-Mantel-Haenzel dan Pengujian Kehomogenan Odds Ratio
\end{abstract}

\section{PENDAHULUAN}

Penurunan angka pengangguran merupakan salah satu target dalam pembangunan. Angka pengangguran yang tinggi disuatu wilayah menjadi salah satu indikator masih rendahnya tingkat kesejahteraan masyarakatnya.

Secara teori, pengangguran dapat dibagi kedalam dua kelompok, yaitu pengangguran terpaksa (involuntary unnemployment) dan pengangguran sukarela (voluntary unemployment). Yang dimaksud pengangguran terpaksa adalah jika seseorang terpaksa tidak bekerja karena tidak ada pekerjaan, sedangkan yang dimaksud pengangguran sukarela adalah seseorang yang sengaja tidak bekerja karena berbagai faktor yang melatarbelakangi keputusannya. Salah satu faktor yang menjadi penyebabnya adalah pendidikan. Menurut Wirosuhardjo (1988) dalam setyadi (1997) menyatakan bahwa semakin tinggi tingkat pendidikan maka makin tinggi aspirasi untuk mendapatkan kedudukan atau kesempatan kerja yang sesuai. Hal ini membuat seseorang akan membutuhkan waktu yang lebih lama dalam mempertimbangkan tawaran pekerjaan yang diterimanya. Bila tawaran tersebut dirasa belum sesuai, maka keputusan untuk menganggur menjadi pilihan. Selain itu menurut Fa'atin (2010) yang menganalisis pengangguran perempuan di 10 provinsi di Indonesia, menggunakan analisis deskriptif didapat indikasi, fenomena pengangguran sukarela juga terjadi pada wanita yang sudah menikah. Perempuan pada umumnya bukan merupakan orang yang bertanggungjawab mencari nafkah utama keluarga, sehingga bila tidak bekerja bukan merupakan suatu hal yang aneh. Kebutuhan sehari-hari perempuan yang sudah menikah biasanya ditanggung oleh suami. Perempuan baru bekerja dan mengambil alih tanggung jawab perekonomian jika keadaan ekonomi keluarga kurang mendukung (Drago, dkk, 2004). Oleh karenanya kecendrungan perempuan yang sudah menikah menganggur lebih besar dibandingkan perempuan yang belum menikah maupun yang berstatus sudah pernah kawin.

Kabupaten Kepahiang sebagai salah satu kabupaten di Provinsi Bengkulu, memiliki tingkat pengangguran terbuka (TPT) sebesar 4,92 persen pada tahun 2015 (BPS, 2015). Angka tersebut menempatkan Kabupaten Kepahiang diposisi keempat sebagai kabupaten dengan angka TPT tertinggi di Provinsi Bengkulu. Selanjutnya jika ditilik lebih dalam berdasarkan jenis kelamin, 
pada tahun 2015 di Kabupaten Kepahiang, dari 582.438 orang jumlah angkatan kerja laki-laki, yang merupakan pengangguran mencapai 25.861 orang. Sedangkan diantara 368.569 orang angkatan kerja perempuan, 20.829 orang merupakan pengangguran. Meski secara absolut jumlah pengangguran perempuan lebih rendah dari laki-laki namun bila dibanding jumlah angkatan kerja masing-masing, maka angka pengangguran perempuan lebih tinggi dari lakilaki, yaitu 5,65 persen, sedangkan angka pengangguran laki-laki sebesar 4,44 persen. Kondisi angka pengangguran perempuan lebih tinggi dari laki-laki sudah terjadi konsisten dari tahun 2011 hingga sekarang.

Tabel 1. Tingkat Pengangguran Terbuka di Kabupaten Kepahiang berdasarkan jenis kelamin dari Tahun 2011-2015 (persen)

\begin{tabular}{|l|l|l|}
\hline \multicolumn{1}{|c|}{ Tahun } & \multicolumn{1}{|c|}{ laki-laki } & \multicolumn{1}{c|}{ Perempuan } \\
\hline 2011 & 2.34 & 3.37 \\
\hline 2012 & 1.87 & 2.95 \\
\hline 2013 & 3.04 & 4.19 \\
\hline 2014 & 1.51 & 2.67 \\
\hline 2015 & 4.44 & 5.65 \\
\hline
\end{tabular}

Sumber : BPS

Dalam program kerja pemerintahan yang definitif saat ini, salah satu misi yang diemban adalah mengembangkan perekonomian Kabupaten Kepahiang yang berdaya saing, berkeadilan dan memberdayakan ekonomi kerakyatan (http://kepahiangkab.go.id). Dimana salah satu poin didalamnya adalah peningkatan investasi yang menyerap tenaga kerja lokal. Pada tahapan ini, pemerintah daerah melihat bahwa pengangguran yang terjadi di Kabupaten Kepahiang baik laki-laki maupun perempuan lebih disebabkan karena tidak adanya pekerjaan. Hal ini berarti kebijakan yang diambil pemerintah lebih diarahkan untuk mengatasi permasalahan pengangguran terpaksa. Padahal ada indikasi bahwa pengangguran perempuan lebih condong kepada pengangguran sukarela. Jika indikasi ini terbukti maka kebijakan yang menyamaratakan fenomena tersebut dirasa kurang tepat.

Oleh karenanya didalam penelitian ini, penulis mencoba membuktikan apakah indikasi bahwa pengangguran perempuan di Kabupaten Kepahiang merupakan pengangguran sukarela adalah benar. Tolak ukur yang digunakan adalah:

* Tahap pertama akan dilihat apakah terdapat hubungan antara tingkat pendidikan perempuan dengan status kegiatannya yaitu pengangguran. Orang dengan pendidikan tinggi cenderung untuk menganggur karena keinginan orang yang berpendidikan tinggi bekerja dengan upah yang tinggi, menyebabkan mereka lebih memilih tidak bekerja daripada bekerja namun dibayar dengan upah yang rendah (kingdon dan Knight, 2000). Hal ini juga diperkuat oleh Dhanani (2004), bahwa penganggur terbuka lebih banyak yang berpendidikan tinggi dan berjenis kelamin perempuan. Jika terdapat hubungan antara tingkat pendidikan dengan status kegiatan yaitu pengangguran pada perempuan usia 15 tahun, maka akan dianalisa lebih lanjut dengan variabel kontrol status perkawinan

* Tahap kedua akan dilihat hubungan antara tingkat pendidikan perempuan dengan status kegiatannya yaitu pengangguran, menggunakan variabel kontrol status perkawinan. Hubungan antara tingkat pendidikan perempuan dengan status kegiatannya yaitu pengangguran seharusnya cenderung lebih besar saat perempuan tersebut berstatus kawin. Berdasarkan budaya di Indonesia biasanya perempuan yang sudah menikah kebutuhan hidupnya ditanggung oleh suaminya. Sedangkan perempuan yang belum kawin maupun yang pernah berstatus kawin harus menanggung kehidupannya sendiri sehingga lebih cenderung untuk bekerja.

Pengangguran perempuan di Kabupaten Kepahiang dapat dikatakan pengangguran sukarela jika terbukti bahwa hubungan antara tingkat pendidikan perempuan dengan status kegiatannya yaitu pengangguran cenderung lebih banyak saat perempuan tersebut berstatus kawin. 


\section{METODE PENELITIAN}

Penelitian ini menggunakan data sekunder yang berasal dari survei Angkatan Kerja Nasional (Sakernas) Kabupaten Kepahiang Provinsi Bengkulu pada Agustus 2015. Data disajikan dalam bentuk tabel kontingensi tiga arah. Adapun yang menjadi variabel $\mathrm{X}$ adalah tingkat pendidikan. Variabel Y adalah status kegiatan. Sedangkan variabel $Z$ adalah status perkawinan. Data yang digunakan adalah perempuan usia 15 tahun.

Metode analisis yang digunakan adalah:

- Analisis tabel Kontingensi 3 Arah

Pada tahapan ini, data akan dianalisis, baik secara parsial maupun secara marginal.

- Uji Odds Ratio

Uji Odds Ratio adalah uji perbandingan dari dua odds. Pengertian odds adalah peluang terjadinya suatu kejadian dibandingkan peluang tidak terjadinya kejadian tersebut.

Adapun rumusnya sebagai berikut:

Odds $=\theta_{i}(j, k)=\frac{\pi_{j \mid h}}{\pi_{k \mid h}}, j \neq k=1, \ldots, J ; i=1, \ldots, I$

Odds Ratio $=\theta_{h i}(j, k)=\frac{\theta_{h}(j, k)}{\theta_{i}(j, k)}$ atau $\frac{n_{11} \cdot n_{22}}{n_{12} \cdot n_{21}}$

Dengan selang kepercayaan $\log \hat{\theta} \pm Z_{\alpha / 2} A S E(\log \hat{\theta})$, dimana

$\operatorname{ASE}(\log \hat{\theta})=\sqrt{\frac{1}{n_{11}}+\frac{1}{n_{12}}+\frac{1}{n_{21}}+\frac{1}{n_{22}}}$

Jika selang kepercayaan mengurung nilai satu maka dianggap tidak ada asosiasi diantara dua variabel.

- Metode Cochran-Mantel-Haenzel

Metode Cochran-Mantel-Haenzel digunakan untuk menguji independensi bersyarat X-Y pada variabel kontrol $Z$ tertentu. Dalam eksperimen ini, metode Cochran-Mantel-Haenzel dilakukan untuk melihat apakah ada asosiasi antara tingkat pendidikan (X) dengan respon status kegiatan $(\mathrm{Y})$ berdasarkan status perkawinan $(\mathrm{Z})$ pada perempuan usia 15 tahun.

dengan:

$$
C M H=\frac{\left[\sum_{k}\left(n_{11 k}-\mu_{11 k}\right)\right]^{2}}{\sum_{k} \operatorname{var}\left(n_{11 k}\right)}
$$

$$
\begin{aligned}
& \mu_{11 k}=E\left(n_{11 k}\right)=\frac{n_{1 . k} \cdot n_{.1 k}}{n_{. k}} \\
& \operatorname{var}\left(n_{11 k}\right)=\frac{n_{1 . k} \cdot n_{2 . k} \cdot n_{.1 k} \cdot n_{.2 k}}{n_{. . k}{ }^{2}\left(n_{. . k}-1\right)}
\end{aligned}
$$

- Uji Homogenitas Odds Ratio

Uji ini digunakan untuk menguji apakah Odds ratio antara tingkat pendidikan dengan status kegiatan, homogen pada kedua kategori status perkawinan.

$$
B D=\sum \frac{\left(n_{i j k}-\hat{\mu}_{i j k}\right)^{2}}{\hat{\mu}_{i j k}}
$$

Adapun konsep-konsep yang dipakai didalam penelitian ini adalah sebagai berikut:

- Angkatan kerja adalah penduduk usia kerja (15 tahun dan lebih) yang bekerja, atau punya pekerjaan namun sementara tidak bekerja dan pengangguran.

- Tingkat pendidikan adalah jenjang pendidikan yang diikuti. Tingkat pendidikan terbagi kedalam dua kategori yaitu pendidikan tinggi dan pendidikan rendah. Yang dimaksud pendidikan tinggi apabila seseorang sudah menamatkan jenjang pendidikan 
SMA keatas yang dibuktikan dengan kepemilikan ijazah. Sedangkan yang termasuk dalam kategori pendidikan rendah adalah seseorang yang memiliki ijazah SMP kebawah, termasuk yang tidak tamat SD dan yang tidak pernah sekolah.

- Status kegiatan adalah kegiatan utama yang dilakukan selama seminggu terakhir dengan waktu terbanyak. Adapun status kegiatan terbagi dalam 2 kategori yaitu pengangguran dan bekerja. Pengangguran didefinisikan sebagai bagian dari angkatan kerja yang tidak bekerja atau sedang mencari pekerjaan (baik bagi mereka yang belum pernah bekerja sama sekali maupun yang sudah pernah bekerja), atau sedang mempersiapkan suatu usaha, mereka yang tidak mencari pekerjaan karena merasa tidak mungkin untuk mendapatkan pekerjaan dan mereka yang sudah memiliki pekerjaan tetapi belum mulai bekerja. Bekerja adalah kegiatan ekonomi yang dilakukan oleh seseorang dengan maksud memperoleh atau membantu memperoleh pendapatan atau keuntungan, paling sedikit 1 jam (tidak terputus) dalam seminggu yang lalu. Kegiatan tersebut termasuk pula kegiatan pekerja tak dibayar yang membantu dalam suatu usaha/kegiatan ekonomi.

- Status perkawinan merupakan status perkawinan responden pada saat pendataan. Status perkawinan dikelompokkan menjadi 2 yaitu kawin dan tidak kawin. Tidak kawin disini adalah orang dengan status belum kawin maupun pernah kawin. Pernah kawin disini adalah seseorang dengan status cerai mati atau cerai hidup.

\section{HASIL DAN PEMBAHASAN}

Objek dalam penelitian ini adalah perempuan usia 15 tahun keatas di Kabupaten Kepahiang Provinsi Bengkulu. Adapun data disajikan dalam tabel kontingensi sebagai berikut:

Tabel 2. Penduduk Perempuan usia 15 tahun Berdasarkan tingkat Pendidikan, Status Kegiatan dan Status Perkawinan di Kabupaten Kepahiang Tahun 2015 (orang)

\begin{tabular}{|l|l|l|l|}
\hline \multirow{2}{*}{ Status Perkawinan } & \multicolumn{2}{|c|}{ Tingkat Pendidikan } & \multicolumn{2}{c|}{ Status Kegiatan } \\
\cline { 3 - 4 } & & \multicolumn{1}{c|}{ Pengangguran } & \multicolumn{1}{c|}{ Bekerja } \\
\hline \multirow{3}{*}{ kawin } & Pendidikan tinggi & 373 & 5.432 \\
\cline { 2 - 4 } & Pendidikan rendah & 281 & 14.945 \\
\hline \multirow{3}{*}{ single } & Pendidikan tinggi & 798 & 2.981 \\
\cline { 2 - 4 } & Pendidikan rendah & 278 & 2.727 \\
\hline
\end{tabular}

Sumber : BPS Data Sakernas, diolah

Untuk membuktikan apakah pengangguran perempuan di Kabupaten Kepahiang merupakan pengangguran sukarela maka akan dilakukan tahapan-tahapan berikut ini:

* Tahap pertama akan dilihat apakah terdapat hubungan antara tingkat pendidikan perempuan dengan status kegiatannya yaitu pengangguran.

Metode yang akan digunakan pada tahap pertama ini adalah:

\section{Analisis Tabel Kontingensi 3 arah}

Pada tahapan ini, data akan dianalisis secara marginal.

Tabel Marginal X dan Y

\begin{tabular}{|l|l|l|}
\hline \multirow{2}{*}{\multicolumn{1}{|c|}{ Tingkat Pendidikan }} & \multicolumn{2}{c|}{ Status Kegiatan } \\
\cline { 2 - 3 } & \multicolumn{1}{c|}{ Pengangguran } & \multicolumn{1}{c|}{ Bekerja } \\
\hline Pendidikan tinggi & 1.171 & 8.413 \\
\hline Pendidikan rendah & 559 & 17.672 \\
\hline
\end{tabular}

Uji Odds Ratio Marginal 


$$
\begin{aligned}
\theta_{X Y}= & \frac{n_{11} \cdot n_{22}}{n_{21} \cdot n_{12}} \\
& =\frac{1.171 \times 17.672}{559 \times 8.413}=4,40
\end{aligned}
$$

Hasil diatas dapat diinterpretasikan bahwa perempuan dengan pendidikan tinggi cenderung 4,40 kali lebih banyak berstatus pengangguran dibandingkan perempuan dengan pendidikan rendah. Dengan menggunakan $\alpha=0.05$ didapat selang kepercayaan diantara 3,97 dan 4,88. Hal ini mengindikasikan bahwa memang terdapat asosiasi antara tingkat pendidikan dengan status kegiatan perempuan usia 15 tahun.

Dari hasil diatas dapat dikatakan bahwa tolak ukur yang pertama telah terpenuhi, maka akan dianalisis lebih lanjut ketahap kedua.

* Tahap kedua akan dilihat hubungan antara tingkat pendidikan perempuan dengan status kegiatannya yaitu pengangguran, menggunakan variabel kontrol status perkawinan

Metode yang akan digunakan pada tahap kedua ini adalah:

Analisis Tabel Kontingensi 3 arah

Pada tahapan ini, data akan dianalisis secara parsial maupun marginal.

- Secara Parsial

Tabel parsial $\mathrm{X}$ dan $\mathrm{Y}$ saat $\mathrm{Z}$ berkategori kawin

Z=kawin

\begin{tabular}{|l|l|l|}
\hline \multirow{2}{*}{\multicolumn{1}{c|}{ Tingkat Pendidikan }} & \multicolumn{2}{c|}{ Status Kegiatan } \\
\cline { 2 - 3 } & Pengangguran & Bekerja \\
\hline Pendidikan tinggi & 373 & 5.432 \\
\hline Pendidikan rendah & 281 & 14.945 \\
\hline
\end{tabular}

Uji Odds Ratio Bersyarat

$$
\begin{aligned}
\theta_{X Y}(\text { kawin }) & =\frac{n_{11} \cdot n_{22}}{n_{21} \cdot n_{12}} \\
= & \frac{373 \times 5.432}{281 \times 14.945}=3,65
\end{aligned}
$$

Hasil diatas dapat diinterpretasikan bahwa ketika berstatus kawin, perempuan dengan pendidikan tinggi cenderung 3,65 kali lebih banyak berstatus pengangguran dibandingkan perempuan dengan pendidikan rendah.

Dengan menggunakan $\alpha=0.05$ didapat selang kepercayaan diantara 3,12 dan 4,28. Hal ini mengindikasikan bahwa memang terdapat asosiasi antara tingkat pendidikan dengan status kegiatan perempuan usia 15 tahun pada saat perempuan tersebut berstatus kawin.

Tabel parsial $\mathrm{X}$ dan $\mathrm{Y}$ saat $\mathrm{Z}$ berkategori tidak kawin Z=tidak kawin

\begin{tabular}{|c|c|c|}
\hline \multirow{2}{*}{ Tingkat Pendidikan } & \multicolumn{2}{|c|}{ Status Kegiatan } \\
\cline { 2 - 3 } & Pengangguran & Bekerja \\
\hline Pendidikan tinggi & 798 & 2.981 \\
\hline Pendidikan rendah & 278 & 2.727 \\
\hline
\end{tabular}


Uji Odds Ratio Bersyarat

$$
\begin{array}{r}
\theta_{X Y}(\text { tidak kawin })=\frac{n_{11} \cdot n_{22}}{n_{21} \cdot n_{12}} \\
=\frac{798 \times 2.727}{278 \times 2.981}=2,63
\end{array}
$$

Hasil diatas dapat diinterpretasikan bahwa ketika berstatus tidak kawin, perempuan dengan pendidikan tinggi cenderung 2,63 kali lebih banyak berstatus pengangguran dibandingkan perempuan dengan pendidikan rendah.

Dengan menggunakan $\alpha=0.05$ didapat selang kepercayaan diantara 2,27 dan 3,04. Hal ini mengindikasikan bahwa memang terdapat asosiasi antara tingkat pendidikan dengan status kegiatan perempuan usia 15 tahun pada saat perempuan tersebut berstatus tidak kawin.

Selanjutnya akan dilihat apakah ada asosiasi antara tingkat pendidikan dengan status perkawinan dan status perkawinan dengan status kegiatan pada perempuan usia 15 tahun.

Tabel Marginal antara X dan Z

\begin{tabular}{|c|c|c|}
\hline \multirow{2}{*}{ Tingkat Pendidikan } & \multicolumn{2}{|c|}{ Status Perkawinan } \\
\cline { 2 - 3 } & Kawin & Tidak Kawin \\
\hline Pendidikan tinggi & 5805 & 3.779 \\
\hline Pendidikan rendah & 15.226 & 3.005 \\
\hline
\end{tabular}

$\theta_{X Z}=\frac{n_{11} \cdot n_{22}}{n_{21} \cdot n_{12}}$

$$
=\frac{5.805 \times 3.005}{15.226 \times 3.779}=0,30
$$

Tabel Marginal antara $Z$ dan $Y$

\begin{tabular}{|c|c|c|}
\hline \multirow{2}{*}{ Status Perkawinan } & \multicolumn{2}{|c|}{ Status Kegiatan } \\
\cline { 2 - 3 } & Pengangguran & Bekerja \\
\hline Kawin & 654 & 1.076 \\
\hline Tidak Kawin & 20.377 & 5.708 \\
\hline
\end{tabular}

$$
\begin{aligned}
\theta_{Z Y}= & \frac{n_{11} \cdot n_{22}}{n_{21} \cdot n_{12}} \\
& =\frac{654 \times 5.708}{20.377 \times 1.076}=0,17
\end{aligned}
$$

Dari nilai kedua Odds ratio diatas terlihat bahwa kedua nilai tersebut tidak sama dengan satu. Hal ini mengindikasikan bahwa terdapat asosiasi antara tingkat pendidikan dengan status perkawinan dan status perkawinan dengan status kegiatan.

Dari hasil analisis menggunakan tabel parsial maupun tabel marginal terlihat bahwa memang ada asosiasi (hubungan) antara tingkat pendidikan, status kegiatan dan status perkawinan pada perempuan usia 15 tahun.

Untuk lebih memastikan apakah ada asosiasi antara tingkat pendidikan dengan status kegiatan pada masing-masing kategori pada status perkawinan, maka dilakukan pengujian hipotesis menggunakan statistik uji Metode Cochran Mantel Haenzel (CMH).

\section{Hipotesis:}

$\mathrm{H}_{0}: \theta_{x y(k)}=1, \forall k$

$\mathrm{H}_{0}: \theta_{x y(k)} \neq 1$, untuk beberapa $k$

Statistik Uji:

$$
C M H=\frac{\left[\sum_{k}\left(n_{11 k}-\mu_{11 k}\right)\right]^{2}}{\sum_{k} \operatorname{var}\left(n_{11 k}\right)}
$$

dengan: 


$$
\begin{aligned}
& \mu_{11 k}=E\left(n_{11 k}\right)=\frac{n_{1 . k} \cdot n_{.1 k}}{n_{. . k}} \\
& C M H=\frac{\left[\sum_{k}\left(n_{11 k}-\mu_{11 k}\right)\right]^{2}}{\sum_{k} \operatorname{var}\left(n_{11 k}\right)}=\frac{[(373-180,52)+(798-599,38)]^{2}}{(126,63+223,42)}=436,96
\end{aligned}
$$

\section{Kriteria Uji:}

Tolak $\mathrm{H}_{0}$ jika $C M H \geq \chi^{2}{ }_{\alpha,(k-1)} \quad ; \mathrm{k}=2, \mathrm{a}=0,05$

Dimana $\chi_{0,05,(1)}^{2}=3.84$

Karena $C M H \geq \chi_{\alpha,(k-1)}^{2}$, maka tolak $H_{0}$, artinya ada asosiasi antara tingkat pendidikan dengan status kegiatan pada perempuan usia 15 tahun pada kedua kategori status perkawinan dengan tingkat kepercayaan 95 persen.

Selanjutnya akan diuji apakah Odds Ratio antara tingkat pendidikan dengan status kegiatan homogen, pada kedua kategori status perkawinan menggunakan Uji Homogenitas Odds Ratio.

\section{Hipotesis:}

$H_{0}=\theta_{X Y}($ kawin $)=\theta_{X Y}($ tidak kawin $)$

$H_{1}=\theta_{X Y}\left(\right.$ kawin $\neq \theta_{X Y}($ tidak kawin $)$

\section{Statistik Uji:}

$$
\begin{gathered}
B D=\sum \frac{\left(n_{i j k}-\hat{\mu}_{i j k}\right)^{2}}{\hat{\mu}_{i j k}} \\
B D=\frac{(373-180,52)^{2}}{180,52}+\cdots+\frac{(2.727-2528,38)^{2}}{2528,38}=9,1417
\end{gathered}
$$

\section{Kriteria Uji:}

Tolak $\mathrm{H}_{0}$ jika $B D \geq \chi^{2}{ }_{\alpha,(k-1)} \quad ; \mathrm{k}=2, \mathrm{a}=0,05$

Dimana $\chi_{0,05,(1)}^{2}=3.84$

Karena $B D \geq \chi_{\alpha,(k-1)}^{2}$, maka tolak $H_{0}$, artinya Odds Ratio antara tingkat pendidikan dengan status kegiatan pada kedua kategori status perkawinan tidak homogen dengan tingkat kepercayaan 95 persen.

Karena tidak terjadi asosiasi homogen, maka Odds Ratio berbeda antar kategori pada status perkawinan. Dari penghitungan didapat bahwa $\theta_{X Y}($ kawin $)=3,65$ dan $\theta_{X Y}$ (tidak kawin) $=2,65$. Dari hasil ini dapat dikatakan bahwa perempuan usia 15 tahun dengan pendidikan tinggi cenderung lebih banyak berstatus pengangguran pada saat berstatus kawin, dibandingkan perempuan yang berstatus tidak kawin. Hal ini berarti tolak ukur yang kedua telah terpenuhi, sehingga dapat dikatakan benar bahwa pengangguran perempuan di Kabupaten Kepahiang merupakan pengangguran sukarela (voluntary unemployment).

\section{KESIMPULAN}

Dari hasil pengujian, dapat ditarik beberapa kesimpulan:

$>$ Terdapat hubungan (asosiasi) antara tingkat pendidikan dengan status kegiatan pada penduduk perempuan usia 15 tahun di Kabupaten Kepahiang, yaitu perempuan dengan pendidikan tinggi cenderung 4,40 kali lebih banyak berstatus pengangguran dibandingkan perempuan dengan pendidikan rendah.

$>$ Asosiasi antara tingkat pendidikan dengan status kegiatan pada penduduk perempuan usia 15 tahun di Kabupaten Kepahiang juga dipengaruhi oleh status perkawinannya. Perempuan yang berpendidikan tinggi cenderung lebih banyak berstatus pengangguran pada saat berstatus kawin, dibandingkan perempuan yang berstatus tidak kawin.

$>$ Dari kedua hal diatas dapat dikatakan bahwa pengangguran perempuan di Kabupaten Kepahiang merupakan pengangguran sukarela (voluntary unemployment). 


\section{Yosep Oktavianus Sitohang}

Dengan adanya gejala pengangguran sukarela pada perempuan di Kabupaten Kepahiang, maka tingginya angka pengangguran perempuan di wilayah ini seharusnya bukan merupakan suatu masalah. Kebijakan yang menempatkan fenomena pengangguran terpaksa dan pengangguran sukarela pada kedudukan yang sama dirasa kurang tepat.

Dalam penelitian ini belum diteliti lebih dalam mengenai alasan yang membuat perempuan di Kabupaten Kepahiang memilih untuk menjadi pengangguran sukarela. Oleh karenanya agar dapat memberikan masukkan yang lebih komprehensif kepada pemerintah setempat, untuk penelitian kedepan perlu memperhatikan hal tersebut.

\section{DAFTAR PUSTAKA}

Agresti, Alan. 2007. An Introduction to Categorical Data Analysis, Second Edition. John Wiley\&Sons Inc, USA.

Badan Pusat Statistik [BPS] Provinsi Bengkulu. 2015. Keadaan Angkatan Kerja di Provinsi Bengkulu agustus 2015. Bengkulu: Perum Percetakan Negara RI.

Dhanani, Shafiq. (2004). Unemployment and Underemployment in Indonesia, 19762000: Paradoxes and Issues. International Labour Office, Geneva.

Drago, Robert, David Black dan Mark Woode. 2004. Female Breadwinner Families: Their Existence, Persistence and Source. IZA DP No. 1308.

Fa'atin, Ana. 2010. Analisis Pengangguran Perempuan: Apakah Menjadi Penganggur Merupakan Pilihan Sukarela?. Thesis pada Program Pascasarjana kependudukan dan ketenagakerjaan. Universitas Indonesia.

Kingdon, Geeta Gandhi dan John Knight. 2001. Unemployment in South Africa: the nature of the beast. The Labour Economics Seminar. University of oxford.

Setyadi, Dodi. 1997. Analisis Pengangguran Tenaga Kerja Terdidik dengan Pendekatan Search Theory pada Pasar Kerja di Jawa Tengah. Thesis pada Program Pascasarjana kependudukan dan ketenagakerjaan. Universitas Indonesia.

http://kepahiangkab.go.id/index.php/visi-dan-misi 